\title{
ISOLATION OF HUMAN FUNGI FROM SOIL AND IDENTIFICATION OF TWO ENDEMIC AREAS OF Cryptococcus neoformans AND Coccidioides immitis.
}

\begin{abstract}
SUMMARY
The present study was carried out in two different areas of Province of Cordoba, Argentina, where there was a suspicious of endemic mycosis. The previous data were the presence of a clinical case of pulmonary cryptococcosis in one area (Alta Gracia) and the previous findings of a high incidence of coccidioidin and cryptococcin reactors in the population of the second one (Villa Dolores). In both areas soil samples for fungi were studied and Cryptococcus neoformans was found in 2/25 samples from Alta Gracia. In Villa Dolores Coccidioides immitis was isolated in 2/40 samples, and C. neoformans in 1/40 samples. Delayed hypersensitivity test with cryptococcin was determined in the population from Alta Gracia and it was found to be $5.3 \%$. Positive cutaneous tests with coccidioidin $(33.8 \%)$ and cryptococcin $(31.9 \%)$ in Villa Dolores were obtained. With these findings two endemic areas of systemic mycoses in Cordoba, Argentina were delimited.
\end{abstract}

KEY WORDS: Endemic areas: Human pathogenic fungi; Epidemiology.

\section{INTRODUCTION}

Coccidioidomycosis is a mycotic disease caused by a dimorphic fungus, Coccidioides immitis. Human infection occurs by inhalation of arthroconidia from the mycelial phase. It has been demonstrated that $60 \%$ of the infections are asymptomatic, and they are detected by cutaneous tests of delayed hypersensitivity to coccidioidin. This test is used to quantify the infected people and it helps to determine the endemic area $^{3}$.
Coccidioidomycosis has a well defined geo graphic distribution, related to the presence of the fungus of the soil ${ }^{7}$. The fungus has been isola ted from soil samples in several areas in the Ame rican Continent.

The epidemiology of coccidioidomycosis in Argentina was studied in detail by NEGRONI et $\mathrm{al}^{13}$, who made the first investigation in 1966 .

(1) Parasitologia y Micologia, Dpto. Bioquimica Clinica. Facultad de Ciencias Quimicas. Universidad Nacional de Cordoba, Argentina.

(2) Medicina Interna. Facultad de Ciencias Medicas. Universidad Nacional de Cordoba, Argentina

(3) Centro de Micologia. Facultad de Medicina. Universidad Nacional de Buenos Aires, Argentina

Address for correspondence: Dra. Diana Masih. Facultad de Ciencias Quimicas. Universidad Nacional de Cordoba. CC 61 Suc. 16. Ciudad Universitaria. (5016) Cordoba, Argentina 
RUBINSTEIN, H.; MARTICORENA, B.; MASIH, D.; BORLETTO, N.; VEGA, R.; VARENGO, H. \& NEGRONI, R. - Isolation of human fungi from soil and identification of two endemic areas of Cryptococcus neoformans and Coccidioides. Rev. Inst. Med. trop. Sáo Paulo, 31 (1): 1 6, 1989.

The saprophytic phase of this fungus lives in sandy or clayey soils in certain arid areas with annual rainfall not over $700-900 \mathrm{~mm}$; in these regions the wet season is followed by a dry and dusty one with dust storms which disseminate propagules to great distances.

C. neoformans is the etiologic agent of cryp tococcosis, a systemic mycosis of universal dis tribution.

The fungus was isolated from the soil for the first time by FMMONS in $1951^{4}$. Later on, it was found in pigeons' excrements and soil samples ${ }^{2}$ $2,5,8$. The frequency of isolation in the samples oscilated between $41 / 90$ and $72 / 201$. These fin dings lead to speculate that $\mathbf{C}$. neoformans is ubicuous in nature and may be easily isolated However, it was found in 1974 by FELTON et al. in only $4 / 538$ soil samples collected at random in Oklahoma, USA. In samples taken from sites near the houses of patients infected with cryptococcosis, the fungus was isolated in $25 / 270 \mathrm{sam}$ ples. The differences in these figures would sug gest that distribution in soil is not uniform ${ }^{6}$.

The absence of a specific and sensitive anti gen in addition to the particular host parasite relation that induces the excess of $\mathbf{C}$. neoformans capsular antigen producing a state of im munotolerance would explain the delay suffered by conductive studies to determinate cryptococ cosis infections.

The first epidemiologic survey was made by MUCHMORE et $\mathrm{al}^{12}$ in Oklahoma in 1968, who determined the infection index of $32 \%$. Later on in São Paulo, Brasil, LACAZ et al. ${ }^{9}$ obtained $4.3 \%$ of positivity. In Argentina the first survey made on individuals in the Province of Cordoba revealed a $14 \%$ infection index ${ }^{11}$.

This paper was based on two former expe riences; the study of a case of pulmonary cryptococcosis in a man from Alta Gracia; and the high Coccidioides infection index found in Traslasier ra (Villa Dolores) in a previous survey. The purposes of this work were to isolate C. immitis and $C$. neoformans from soil samples from the places in study and to determine the Cryptococcus infection index in the people who live in Alta Gracia (Cordoba).

\section{MATERIALS AND METHODS}

\section{Phytogeographic characteristics of the studied} areas

The Province of Cordoba is situated in the middle of the Argentina. The region of Traslasierra at which Villa Dolores city belongs is loca ted in the West of the Province of Cordoba, limited at the East by hills with a maximum hight of $2.884 \mathrm{~m}$. Alta Gracia city is situated in the centre of Cordoba. Both areas are characterized by low hills and plains with predominantly summer rainfall reaching 600 to $800 \mathrm{~mm}$ annually. The mean annual temperature is $18^{\circ} \mathrm{C}$ with maximum mean temperature of $24-25^{\circ} \mathrm{C}$ and minimum mean temperature of $10-11^{\circ} \mathrm{C}$. The autochthonous vegetation is a xerophilous forest with trees like carob tree quebracho; there are many birds in all the region with predominance of wild pigeons and poultry (Fig. 1).

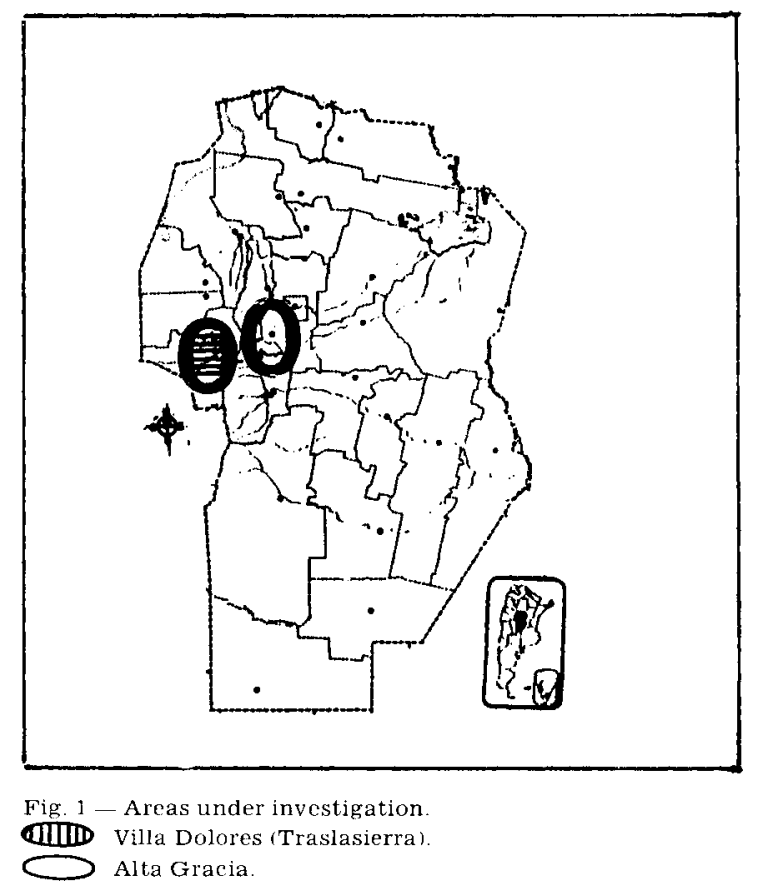

Isolation of the fungus from soil

Soil sampling (houses, squares and streets) and sampling from poultry yards and plucking 
RUBINSTEIN, H:: MARTICORENA, B:: MASIH, D.: BORLETTO. N.: VEGA. R.: VARENGO. H. \& NEGRONI, R. - Isolation of human fungi from soil and identification of two endemic areas of Cryptococcus neoformans and Coccidioides. Rev. Inst. Med. trop. Sāo Paulo, 31 (1): 1 6, 1989

establishment covered 4 zones of the city of Villa Dolores which represent a homogeneous distribution of its territory. Ten samples collected in each zone were inoculated intraperitoneally into 4 mice.

\section{Isolation of Cryptococcus neoformans}

Twenty five soil samples mixed with pigeon excrements and vegetal matter collected in different places of the town were studied. Open areas and surrounding buildings were the places chosen for sampling. The collection was made with ste rile discarded spatulas. The samples were kept in sterile disposable containers at room temperature until used.

All the samples were processed by duplicated following SHIELDS and AJELLO's method ${ }^{14}$ with modifications proposed by CIVILA \& CON TI-DIAZ ${ }^{2}$. The material was spread on Petri dish plaques containing the culture media with the following composition: glucose $10 \mathrm{~g}$, creatinine $780 \mathrm{mg}$, chloramphenicol $50 \mathrm{mg}$, sunflower seed extract $350 \mathrm{ml}$, tap water $650 \mathrm{ml}$, agar $18 \mathrm{~g}$. The preparation of the sunflower seed extract was the following: $70 \mathrm{~g}$ of pulverized sunflower seeds are suspended in $350 \mathrm{ml}$ of distillate water. It is autoclaved at 1.5 atm during 10 minutes and it is filtered through gauze. This media pigments colonies of Cryptococcus neoformans in a dark chestnutbrown color, making it possible to re cognize them macroscopically. The cultures we re incubated at $37^{\circ} \mathrm{C}$ and observed during 10 days.

Test of urease, development in Sabouraud media at $37^{\circ} \mathrm{C}$ and 21 days old mice intracranial inoculation were carried out in order to corroborate the identity of the pigmented strains developed in the used media.

\section{Isolation of Coccidioides immitis}

Forty soil samples were taken at Villa Dolores city. Each sample material $(10-20 \mathrm{~g})$, collected after discarding the superficial layer, with sterile wooden spatulas were put in sterile containers. Then it was suspended in $50 \mathrm{ml}$ of sterile saline solution and chloramphenicol $300 \mu \mathrm{g} / \mathrm{ml}$ with glass beads. Each sample was shaken vigorously and let it rest for 2 hours, it was taken $0.5 \mathrm{ml}$ of the middle layer of supernatant and inocu lated intraperitoneally in 4 mice. The animals were killed 45 days after inoculation. Lung, liver, spleen and brain homogenates were cultured on Sabouraud-dextrose media and incubated at $37^{\circ} \mathrm{C}$ during 30 days. The identification of the isolated strains involved the demonstration of the micelial phase in vitro and its conversion to parasitic form by intratesticular inoculation of guinea pigs.

\section{Antigen}

The cryptococcin used for the delayed type hypersensitivity test was the supernatant of me chanically disrupted cells, prepared from a nondecapsulated $\mathbf{C}$. neoformans strain with a proteic concentration of $1.0 \mathrm{mg} / \mathrm{ml}$ and with a reaction of Iatex particle agglutination for polisaccharide antigen until the $1 / 10.000$ dilution ${ }^{10}$.

The coccidioidin was elaborated by Profes sor Ricardo Negroni in the Centro de Micologia de la Universidad Nacional de Buenos Aires.

\section{People studied}

Tests of delayed, hypersensitivity for cocci dioidin and cryptococcin were made in people from Villa Dolores and Alta Gracia. People of both sexes with ages between 16 and 60 without apparent immunologic compromise, not carriers of diabetes or neoplasias and with no corticoid or cytostatic treatment were selected. As far as possible, people with positive reactions to tuberculin were chosen. Double radial immunodifu sion reaction with coccidioidin was made thorax $\mathrm{X}$-Rays were performed on people with positive skin test.

\section{Cutaneous test}

A conventional technique was applied, 0.1 $\mathrm{ml}$ of antigen on the anterior side of the forearm; reactions were read between 24 and $72 \mathrm{~h}$, indurations over $8 \mathrm{~mm}$ were considered positive.

\section{Clinical case}

Patient O. F. Male, 53 years old, was born in Alta Gracia (Cordoba) where he lives presen- 
RUBINSTEIN, H.: MARTICORENA, B.; MASIH, D.; BORLETTO, N.: VEGA, R.: VARENGO, H. \& NEGRONI, R. - Isolation of human fungi from soil and identification of two endemic areas of Cryptococcus neoformans and Coccidioides. Rev. Inst. Med. trop. Sáo Paulo, 31 (1): 1-6, 1989.

tly; occupation: broker. He started 2 months before the first appointment with pains in the anterior and side region of left hemithorax, without cough, expectoration, dyspnea, fever, anorexia or weight loss. A thorax X-Ray showed a dense homogeneous, round shaped imagen of tumoral appearance with sharp edges and a diameter of approximately $8 \mathrm{~cm}$ in mid peripheric location in the left hemithorax (Figs. 2-3).

The possibility of neoplasia was ruled out by bronchofibroscopy: the biopsy revealed elements compatible with mycosis. The diagnosis could not be confirmed due to the limited size of the sample. Fifteen days later a palpable tumor became evident in the left hemithorax which coincided in the localization with the $\mathrm{X}$ Ray image. Due to this fact an exploratory thoracotomy was made and upon exposing the ribs it was possible to observe in the 5 th intercostal espace the protrusion of a gelatinous tumoral mass which had destroyed the 4 th rib. Several biopsic samples were taken and sent to the my cologic examination. The mycology laboratory reported the presence of a large number of yeast cells with colorless capsule when examined di-

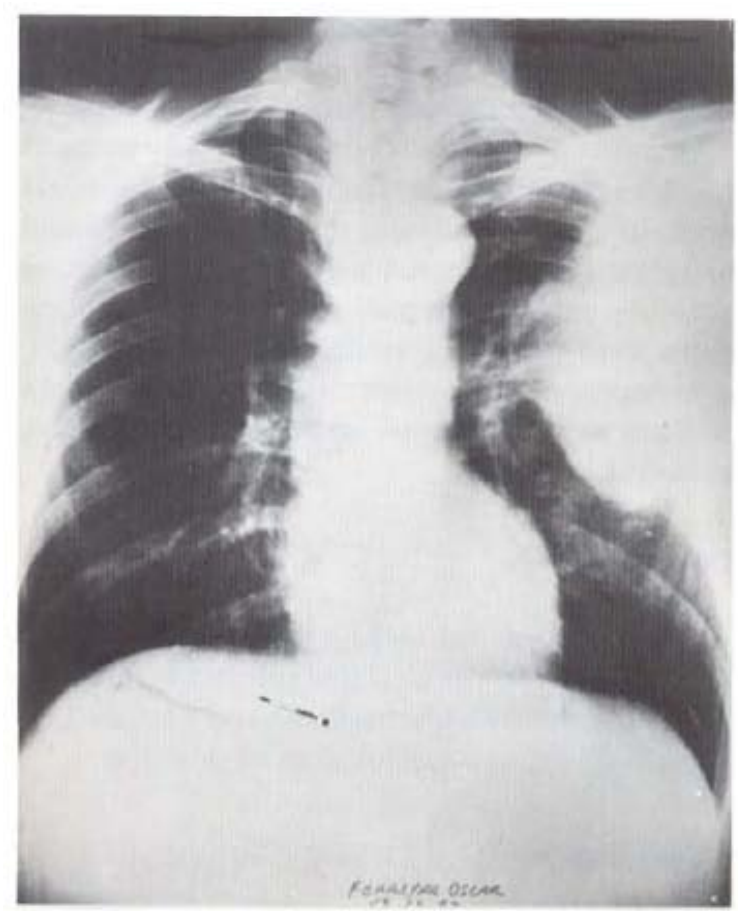

Fig. 2 - Pulmonary cryptococcosis. Chest roentgenogram sho. wing large mass in the left upper lobe.

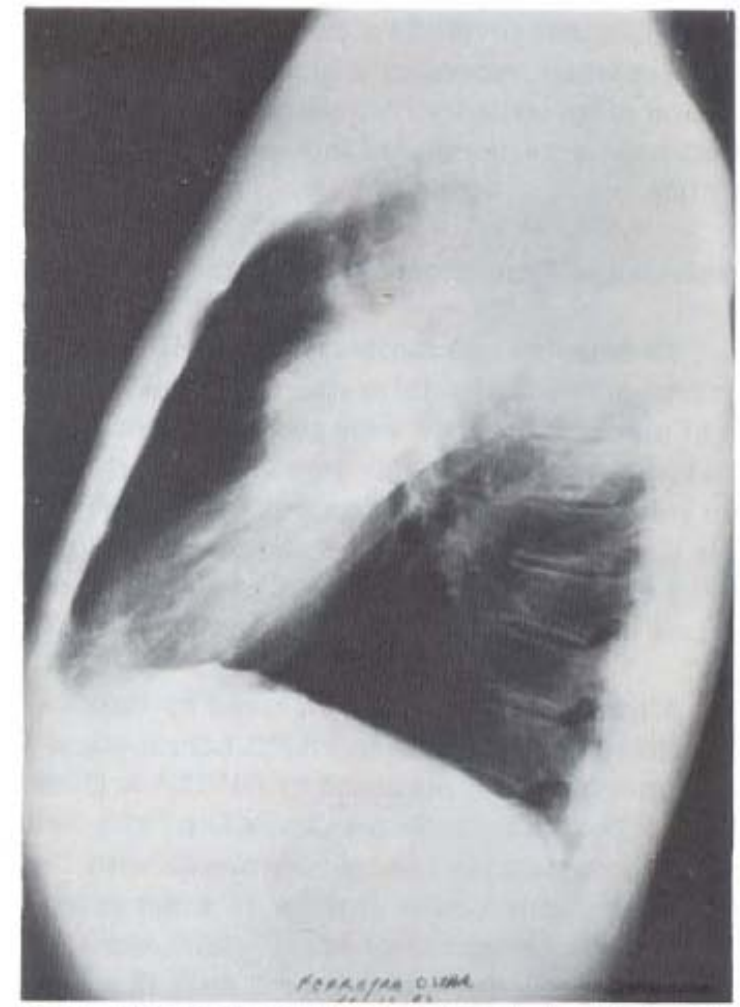

Fig. 3 - Pulmonary cryptococcosis, Lateral view showing the same mass in a posterior location.

rectly with Indian ink. C. neoformans was identified in cultures. This diagnosis was later confirmed by the pathologic examination of the lung biopsy. Counterimmunoelectrophoresis (with cryptococcin) was performed to evaluate antibodies. The results were negative.

\section{RESULTS}

\section{Isolation of fungus from soil}

Of all inoculated animals with soil samples of Villa Dolores one died spontaneously after 7 days. The cultures from its organs were negative. Fifteen days after the inoculation, 2 animals inoculated with a sample obtained from the same poultry yard died spontaneously. It was possible to isolate C. neoformans from its organs. The remaining animals were sacrificed 45 days after the inoculation. The presence of $\mathbf{C}$. immitis was determined in 2 animals inoculated with diffe rent soil samples from the same neighbourhood, 
both presented microscopic lesions in the liver. The typical spherules were observed in direct examinations. The cultures were positive for both animals.

C. neoformans was isolated in 2 of 25 samples studied from Alta Gracia. Macroscopically, these strains presented a creamy appearance and dark brown pigmentation on both sides of the colony, the color was intensified at room temperature after 4 days of incubation at $37^{\circ} \mathrm{C}$. The urease test was positive.

Inoculated mice had to be killed between 20 and 30 days, with no macroscopic lesions in the brain. Due to this fact, this organ was spread on Sabouraud media anci was inoculated again in mice. C. neoformans developed in all cultures. In some cases it was necessary to perform up to 3 passages through mice in order to obtain the encapsulated cell.

\section{Cutaneous test}

Delayed hypersensitivity tests were performed on 65 inhabitans of Villa Dolores, 22 of them were positive to coccidioidin $(33.8 \%)$ and 22 of 69 tested with cryptococcin were also positive (31.9\%). In Alta Gracia city $1 / 19$ positive cutaneous test with cryptococcin was obtained $(5.3 \%)$, (Table 1$)$.

TABLE 1

C. neoformans and C. immitis infection index and isolation in the areas under investigation.

\begin{tabular}{ccc}
\hline Area & Positive skin test & Isolation of fungus \\
& $(\%)$ & from soil
\end{tabular}

cryptococcin coccidioidin C. neoformans C. immitis

\begin{tabular}{lcccc}
\hline Villa & & & & \\
$\begin{array}{l}\text { Dollores } \\
\text { Alta }\end{array}$ & 31.9 & 33.8 & $1 / 40$ & $2 / 40$ \\
Gracia & 5.3 & - & $2 / 25$ & $0 / 40$ \\
\hline
\end{tabular}

\section{DISCUSSION}

In this paper we were able to identify two endemic areas of systemic mycosis in Cordoba, Argentina. (Fig. 1).
In Alta Gracia three requirements, for the identification of endemic areas have been fulfill ed. The first one was the clinical case, charac terized by a pulmonary infection in a patient without immunologic deficit. The second condi tion was the cryptococcin infection index deter minated in a low porcentage of population $(5.3 \%)$. The third requirement was extensively met, the samples of soil fertilized with pigeons excreta obtained in the city allowed the isolation of C. neoformans in two of twenty five samples.

In the previous population survey of Villa Dolores intradermal reactions with coccidioidin and cryptococcin have revealed the existence of a great number of individuals with positive reaction $33.8 \%$ and $31.9 \%$ respectively.

C. immitis was isolated from soil samples in a $2 / 40$ ratio. Besides it was possible to isolate C. neoformans in 1/40 samples. For the first time it was isolated C. neoformans from Argentina and C.immitis from soil in the province of Cordo ba (Villa Dolores).

It is important to remark that the isolation of C. neoformans was made from soil fertilized with poultry excrement and not from pigeon ex crement as advised by the literature ${ }^{2,5,8}$. Mycotic infections caused by $\mathbf{C}$. immitis or $\mathbf{C}$. neoformans have not been known in Villa Dolores be cause there are no specialized laboratories of $\mathrm{My}$ cology in this town.

\section{RESUMEN}

Aislamiento de hongos patogenos de suelo. Identificación de areas endemicas de Cryptococcus neoformans y Coccidioides immitis.

Se presenta un estudio de endemia de mico sis causadas por hongos patogenos primarios en dos zonas de la Provincia de Cordoba, Argentina, donde previamente se diagnostico un caso clini co de criptococosis pulmonar en una de las areas (Alta Gracia) y se encontraron altos indices de infección para C. immitis y C. neoformans en la población de la segunda zona (Villa Dolores).

En ambas regiones se encontraron hongos patogenos en suelos; en Villa Dolores se pudo aislar C. immitis en $2 / 40$ muestras de tierra y en $1 / 40$ muestras C. neoformans. Mientras que 
RUBINSTEIN, H.: MARTICORENA. B.: MASIH, D.: BORLETTO, N.: VEGA, R.: VARENGO, H. \& NEGRONI, R.

- Isolation of human fungi from soil and identification of two endemic areas of Cryptococcus neoformans and Coccidioides. Rev. Inst. Med. trop. São Paulo, 31 (1): 1 6. 6.1989.

en la Cuidad de Alta Gracia se pudo aislar C. neoformans en $2 / 25$ muestras de tierra. El indice de infección de la población con coccidioidina, en Villa Dolores, fue de $33.8 \%$ y con criptococcina de $31.9 \%$. Tambien se determino el indice de in fección de la población con criptococcina en Alta Gracia, el cual fue del $5.3 \%$

\section{REFERENCES}

1. AJELLO, L. - Ocurrence of Cryptococeus neoformans in solls. Amer. J. Hyg., 67: 72-77, 1958.

2. CIVILA. E.\& CONTI DIAZ, I. A. - Aislamiento de Cryptococcus neoformans de excretas secas de palomas en la ciudad de Montevideo Rev. urug. Pat, clin. Microbiol., 3: $41-48,1976$.

3. CONVERSE, J. \& REED R. -- Experimental epidemio logy of coccidiodomycosis. Bact. Rev., 30:678 682, 1966.

4. EMMONS, C. - Isolation of Cryptococcus neoformans from soil. J. Bact., 62: 685-689, 1951.

5. EMMONS. C -.- Saprophytic sources of Cryptococeus neoformans associated with the pigeon. Amer. J. Hyg, 62 $277 \cdot 282,1955$

6. FELTON, F. G; MUCHMORE, H. G.: MCCARTY, R, A. MONROE, P. \& RHOADES, E. R. - Epidemiology of cryptococcosis. Evaluation of patients environment Hith. Lab. Sci.. 11: 201209,1974
7. GEORG, L. \& AJELLO. L. - A selective medium of the isolation of Coccidioides immitis Science. 114: 387389. 1951

8. KAO, C. J \& SCHUARS. P. ... The isolation of cryptococcus neoformans from pigeon nest. Amer. J. clin. Path.. 27. 652663,1952 .

9. LACAZ, C. \& MELHEM, M. ...- Ensaio immunoalergico rom eriptococcina em recrutas de um batalha policial de Sāo Paulo Brasilı. Rev. Hosp. Clın. Fae. Mł'd. S. Paulo. 33: $49 \cdot 51,1978$.

10. MASIH, D.: NEGRONI, R.: NOBILE, R.: RIERA, C. \& RUBINSTEINS, H. -- Nueva cryptococcina para intrader moreacciones. Rev, argent. Micol., 6: 18 23. 1983.

11. MASIH, D : MARTICORENA, B.: BORIETTO, N.: FA RIAS, C. \& NEGRONI. R -- Epidemiologic study of bron chopulmonary mycosis in the Province of Cordoba. Argen tina. Rev. Inst. Med. trop. S. Paulo, 29:5962,1987

12. MUCHMORE, H. G.: FELTON, F.: SALVIN, S \& RHOA DES, E. - Delayed hypersensitivity to cryptococcin in man. Sabouraudia, 6:285288, 1968

13. NEGRONI, P. ... Las blastomicosis y cocridioidomicosis In: Micosis profundas (cutaneas y viceraless. Buenos Aires, Comision de Investigacion Cientifiea, 1966. v. 3.

14. SHIELDS, A. B. \& AJELL,O, L. - Medium for selective iso lation of Cryptococeus neoformans. Science, 151: 208209 , 1966 .

Recebido para publicaçāo em 1191987 